\title{
Identification of the Existing Social Problems and Proposing a Sustainable Social Business Model: Bangladesh Perspective
}

\author{
Farhana Yasmin ${ }^{1}$ \\ ${ }^{1}$ Department of Business Administration in Finance \& Banking, Bangladesh University of Professionals, Mirpur \\ Cantonment, Dhaka, Bangladesh \\ Correspondence: Farhana Yasmin, Department of Business Administration in Finance \& Banking, Bangladesh \\ University of Professionals, Mirpur Cantonment, Dhaka, Bangladesh. E-mail: fyfinancedu@gmail.com
}

Received: August 19, 2019

Accepted: August 31, 2019

Online Published: August 31, 2019

doi:10.5539/ijef.v11n9p81

URL: https://doi.org/10.5539/ijef.v11n9p81

\begin{abstract}
Social Business, comparatively as emerging concept, deals with social objective and betterment while being financially self-sufficient. The profit-maximizing orientation of traditional business firms often ends up with the exploitation of the under-privileged people of the society. Hence this research attempts to explain the prospect of implementing social business by private organizations to address those social problems which are challenging the lives of the under-privileged people of developing country like Bangladesh. The research is an exploratory qualitative research which uses in-depth interviews and survey method from 60 respondents to identify the existing major social problems and regression analysis to discuss the sustainability of social business in solving such problems. The study also proposes a financially sustainable social business model which actually combines the cause driven motive from a social perspective as well as sustainable orientation from business perspective. Finally the research initiates the necessity of implementing this mandatory drive by all socially responsible private organizations as the scopes of social business in serving the under-privileged section of the developing nation is very optimistic and optimal.
\end{abstract}

Keywords: social business, social problem, sustainable social business model, Bangladesh

\section{Introduction}

For a third world country like Bangladesh, it is necessary for private organizations to come forward to help the poor class of people of this least developed nation. The government alone can never be able to solve all the problems. The reason can be lack of expertise, inability to solve, lack of resources, reluctance to handle this issue, etc. Again there have been loads of talks and controversies that involve the cutting off ideology of private sector for an under-developed or developing nation. It has been provoked that private sector for an under-developed or developing economy is nothing but a luxury which costs the under-privileged section of the society one step more of a struggle. Involvement of private sector has also been associated with exploitation of its workers, environment, resources majority of whose burden in turn is borne by the under-privileged people of the society. Hence such scholars who oppose private sector participation have largely relied upon the necessary projects and developments to be taken by the government for the majority of poor people. Some of them argued for NGOs in such an economy so that they will directly work in solving social problems and can be operated with grants and donations of the other class category of the society. But over the time it has been observed that none of the following perception actually benefits the under-privileged people of the society. The reason is clear.

For any under-developed nation the government usually remains over-burdened with so many financial issues and commitments that it is nearly impossible to address the social problems at the root level. Besides, NGOs with grants and donations work for social problems with such a budget constraints that the financial resources available is most of the time not sufficient for addressing the social problems in the society where more than $80 \%$ people are suffering from at least one kind of severe social problem. Therefore this paper tries to introduce a social business model which takes the positives of the both entities stated above which means this business model will not be making profits by exploitation but it is going to address the social problems by solution. Besides this social business being proposed would be self sufficient and sustainable enough to provide and work with enough financial resources and this sustainability in turn provides the social business to be ongoing in its own. 
In the context it is to be noted that the social business concept is still under construction, and has emerged mainly through the on-going experience of Grameen-Group. Hence, a social business is a new form of business between a profit-maximizing and a non-profit organization. Why investors would put money into such a business can be answered with the foundation of the charitable establishments. It shows a desire to give money in a way that benefits other human beings. The social business is self-sustaining, where the investors get their money back. The investor also remains the owner of the company and decides its future course of action. And to establish a new concept, it is necessary to identify and solve the limitations in implementation of such an emerging topic.

For the last couple of months, Social Business is an emerging issue and the mostly discussed topic throughout the world. In a nutshell, Social Business is a way of running private businesses not primarily to earn profit, but to provide a social good and betterment. In the capitalist system, two types of corporate bodies can be distinguished. On the one hand, companies can be seen as profit-maximizing businesses, whose purpose is to create shareholder value. On the other hand, non-profit organizations exist to fulfill a social objective. A social business borrows from both these entities. It has to recover its full costs from its operations, and owners are entitled to recover their invested money. However, the social business is more cause-driven than profit-driven, with the potential to act as a change agent for the world.

A more commonly used and better understood concept is the related model of social enterprise. This term describes broadly 'commercial activity by socially minded organizations'. Social business is therefore a subset of social enterprise, with the specific characteristic that, whereas a social enterprise can be funded by philanthropy or government grant, a true social business should be self-sufficient.

The study has mainly focused on identifying prospects of social business in Bangladesh. In this regard it is evident that Bangladesh is a land of social problems. Not only few in numbers, has it had numerous social problems which are so intense in nature that question the survival of under-privileged section of the society every day. Hence the concept of social business model has been aroused to better address those social issues. Over the years many social enterprises have been introduced keeping in line with the idea of social business concept. Few of them were highly criticized in terms of their usability and some in terms of their sustainability. In the process the social problems have started to remain unmet and social business concept have been questioned without seeking any possible improvements to the idea. Therefore this paper is an attempt to propose a social business model which will address key social problems that have been prevailing in the lives of under-privileged people nowadays.

\section{Literature Review}

Social Business is an emerging concept. Different authors from different part of the world have worked on it. The entire literature is divided into several parts based on the objective of this study:

\subsection{Identifying Social Problems}

As one of the least-developed countries (LDCs), Bangladesh has faced many problems soon from its independence in 1971. Although many initiatives had been taken, the extent of such problems has brought under control, but still not solved entirely. There are many opinions available by different authors regarding the social problems of Bangladesh that hindered the overall growth.

Inconsistency between individual rationality in corporate activity and collective rationality in the socio-economic system is a so-called "social dilemma" problem. According to Kim Kercher, Twenty years ago, activists were faced with environmental and social issues. They are likely to be among the most critical factors shaping government policy and corporate strategy ten years from now. Twenty years ago, local states and countries, national and regional businesses were partly connected. Ten years from now, as individuals and organizations, we will be globally interdependent.

Taking into account several considerations, following social problems seemed to be crucial: illiteracy, unemployment, child labor, arsenic contamination, water pollution, insecure health facility, youth and women empowerment, lack of natural resources, slum dwellers, etc.

To solve such problems, Prof. Dr. Md. Yunus thought of Social Problem as the panacea of these problems. The free market is an extraordinarily powerful tool to bring about prosperity and provide products to consumers. (Yunus 2007) Market actors, aiming to maximize profits, find ways to do more with less. The free market may "exacerbate poverty, disease, pollution, corruption, crime, and inequality". The solution proposed by Professor Yunus is not to model a new system, but to offer a new for utilizing the powers of the market.

This study tries to highlight prospects of social business in several problematic areas including illiteracy, unemployment, child labor, child development, youth development, security, water crisis, malnutrition, women 
empowerment, arsenic contamination, and slum dweller.

\subsection{Social Business Concept}

Social enterprise introduces to the free market economy a totally revolutionary dimension. As Prof. Dr. Md. Yunus has described, a cause-driven business is a social enterprise. The investors or owners can gradually recover the money invested in a social business, but they will not be able to take any dividend beyond that point.

According to him, while trying social business, a company should follow seven principles. The very first principle talks about the objective of the business that will not be the profit maximization like the way it had been so far. Rather the objective must include overcoming one or more social problems like poverty which threatens the survival of people in the society. The second principle stands for the economic and financial sustainability of the social enterprise itself. It has to be self-sufficient financially. The third principle explains the return of investors from the social enterprise which is to get back the total invested amount only. They will never be entitled to get any dividend beyond the amount of investment. The fourth principle talks about the future growth of the social enterprise where company profit after paying off all the investors their due invested amount back, will stay with company for improvement and further expansion. The fifth principle stands for being friendly with the environment while doing the business. It has to be very conscious while doing their business operations. The sixth principle advocates for the better working condition and fair wage of the workers which will be according to the contemporary market standard. Final principle encourages happiness and joy while doing social welfare and putting smile on people's face.

Later on the author Md Yunus also stated the categories that a social business can take.

The very first type of social business deals with social objectives only which focuses on providing a product or service with ethical, social or environmental concern. The second type of social enterprise is a profit-oriented business but is typically owned by the poor or under-privileged section of the society. Hence the social objective will be fulfilled through them gaining direct dividends or by receiving other indirect benefits.

The pioneer author also focused on the components required to make a social business successful. They are culture and technology. According to the author if one socio-economy has both- a good culture and good technology then there will be a quick adaptation of a social approach to do the business fairly. In this incident the probability of success is very high. If one social-economy is constructed in a poor culture but has a good technology then the successful implementation and resulting benefits of social business would require to work through some tough issues. To fight back the poor culture the social approach must need a well-developed implementation strategy to see real success of social business whereas the good technology will help it to remove excuses. Finally if one socio-economy has both-poor culture and poor technology then just having a developed implementation strategy even would not be enough to gain the real success. This will help to gain some of the success but not the real one.

According to Sattar (2012), social business reins the pursuit of profit maximization and hence gives some relief within the capitalist system. In some sector, people have great enthusiasm for social business. They feel comfortable in these sectors with the presence of social business. Referring to the aspects of public health, Donaldson et al. (2011) analyze the reasons why social business represents an important area of consideration for public policy given the limits of traditional businesses. They observe that social businesses in the health care contexts as well as in the non-health care contexts can have a considerable impact on health and overall wellbeing. There must exist social responsibility to conduct social business. As the main purpose of the business is to ensure high benefit to the society, this is critical for the business. Wimmer (2012), while analyzing the activities of Grameen Shakti, describes how a social business can change the daily lives of rural population. She sees the sense of responsibility to the society as the driving force of such a business company. There is a traditional feeling of profit maximization for any business. This is very critical for our social business. And this is observed by Bylund and Mondelli (2009) who identified free-ridings one of the problems in the evolution of social business. They argue that social business is not a widely observed phenomenon because of a weaker incentive to minimize cost and maximize output. They term social business as a very difficult enterprise.

From the above discussion it is very much evident that, a social business is constructed all about having interaction with people but not just selling products. Social Business deals with customer satisfaction and their experience. The concept of social business imposes to listen to what customer perceptions say. It works on a feedback approach no matter if it is positive or negative.

The concept of social business firmly understands that societal people like to connect with other people and obviously not with business entities. From the natural heritance customers like to talk to a real person in any kind 
of stress, struggle or seeking help. It is baseless to think that people will be comfortable sharing their problems with a business. Hence for this purpose social business is basically managed by objectives, precisely not by presence.

\section{Research Methodology}

Methodology may be a description of process, or may be expanded to include a philosophical coherent collection of theories, concepts or ideas as they relate to a particular discipline or field of inquiry. It may refer to nothing more than a simple set of methods or procedures, or it may refer to the rationale and the philosophical assumptions that underline a particular study relative to the scientific method.

\subsection{Research Design}

Research can be defined as the search for knowledge or any systematic investigation to establish facts. Research design may be classified as Exploratory or Descriptive research. This study is basically an exploratory research, as it tries to reveal some factors, boost up new ways, and find drawbacks to make social business more practical. However, this study can be referred as descriptive research with the fact that it attempts to highlight the perception of the societal members about a particular issue.

The study is a combination of both qualitative and quantitative, though high emphasis is put on the qualitative part. Other related quantitative information is used to better describe the concept. Qualitative data is converted into quantitative data in some cases, based on study requirements using statistical tools and software,

As mentioned previously, both qualitative and quantitative data have been used to prepare the report. To collect qualitative data, depth interview has been conducted by personal visits to the business people of various firms, teacher of private, students of the University of Dhaka, and to some employees working at multinational and local firms. And to collect quantitative data, the most common and widely used technique of data collection is also used. The method is survey method. The respondents were surveyed using a structured questionnaire to collect the primary data.

It is to be emphasized that this work is based on data collected from both secondary and primary sources. The secondary sources of data includes the information collected from the online journals, published reports, various books, internet articles, and some foreign and local websites. Internet was also being used for collecting the relevant data which is not available in the books.Primary data is collected in two ways. Firstly, In-Depth Interviews have been conducted to collect insight of the people. Secondly, Survey of the respondents has been undertaken from using a structured questionnaire. The questionnaire was especially designed to find out the objectives of the research.

\subsection{Sample}

The study is conducted to establish an emerging concept. The target population for this study is the private organizations of Bangladesh who have the potentials to adopt the new concept in order to support the sufferers of various social problems. The sampling frame is confined to Dhaka only. The rationales behind this decision are many. Dhaka has the maximum corporate offices and most versatile types of people. Thus, this area will be a representative one for the entire country. Time to collect the data as well as finish the report and cost incurred while conducting this study were other important considerations for such decision.

As indicated above, both qualitative and quantitative have been used for this study from both primary and secondary sources, the sample size finalization is a great consideration for the better fulfillment and greater accuracy of the report. For qualitative study, in-depth interviews have been taken of 5 respondents. To get quantitative data, 60 people have been surveyed in total. The initial sample size was 50 . With $90 \%$ completion rate and 95\% incidence rate, the final sample becomes equal to 60 to be divided into 3 groups: 20 were businessmen, 20 service holders, and 20 students. All the respondents were belonged to Dhaka.

There are different types of sampling method or process available to conduct any research. In this study, both qualitative and quantitative data will be used for exploring an emerging concept and describing consumers' perception of that concept. Thus, both non-probability and probability technique can be useful. For conducting exploratory research, in-depth interviews have been conducted. The samples were taken based on own judgment of the researcher. For descriptive research, surveys have been done. The samples were selected in stratified technique where similar group of people were identified first and then random sampling need to be conducted in order to meet the respondents.

\subsection{Instruments}

The Survey questionnaire is a combination of demographic questions, dichotomous questions, some multiple 
choice questions, and research questions. Demographic questions were asked to group of respondents and their corresponding responses in this emerging concept, dichotomous questions were set to understand the assertiveness on some particular issues, MCQs were given to find out maximum frequencies on some variables, and research questions were measured by 9-points likert scale to track the agreement of the respondents on statements representing the key variables of the study. The developed questionnaire has been pre-tested with few customers to ensure the quality of the questions. Very few modifications needed to incorporate in the survey questionnaire. In order to prepare the questionnaire for in-depth interview, it is required to take help from a professional researcher expert in that field. A sample of both the questionnaires is given in the Appendix section later with the title Appendix A and B.

\subsection{Data Analyzing Tools}

After gathering the data from the Primary and secondary sources, the data were tabulated using a structured format and analyzed using some calculations to sum up the total information. The database is prepared to input data by using the software, SPSS version 16. Frequency and regression analysis were conducted to analyze the findings indicating the challenges and prospects of social problems.

\section{Result and Interpretation}

\subsection{Social Problems in Bangladesh}

Bangladesh is crisscrossed by numerous social problems. Here in this report, a list of 15 social problems is shown to the respondents. The respondents were supposed to rank top 5 social problems faced by Bangladeshi people. These social problems have been derived from the literature available related to this topic.

\section{Top $1^{\text {st }}$ Problem:}

Table 1. Top $1^{\text {st }}$ problem

\begin{tabular}{llccc}
\hline & & Frequency & Percent & Cumulative \% \\
\hline Valid & Illiteracy & 16 & 26.6 & 26.6 \\
& Child Labor & 8 & 13.4 & 40.0 \\
Water Crisis & 12 & 20.0 & 60.0 \\
& Food Adulteration & 6 & 10.0 & 70.0 \\
Youth Degradation & 6 & 10.0 & 80.0 \\
Women Degradation & 6 & 10.0 & 90.0 \\
& Health Problem & 6 & 10.0 & 100.0 \\
& Total & 60 & 100.0 & \\
\hline
\end{tabular}

The table shows that more than $25 \%$ people think illiteracy as the main problem of Bangladesh. Again, water crisis is seemed to be the most severe problem by almost $20 \%$ of the respondents. Apart from these two, child labor, food adulteration, youth degradation, women degradation, and health problem are stated by $10 \%$ of the respondents each.

Top $2^{\text {nd }}$ Problem:

Table 2. Top $2^{\text {nd }}$ problem

\begin{tabular}{llccc}
\hline & Frequency & Percent & Cumulative \% \\
\hline Valid & Lack of Security & 6 & 10.0 & 10.0 \\
& Illiteracy & 6 & 10.0 & 20.0 \\
Unemployment & 6 & 10.0 & 30.0 \\
Water Crisis & 6 & 10.0 & 40.0 \\
Arsenic Contamination & 12 & 20.0 & 60.0 \\
Food Adulteration & 6 & 10.0 & 70.0 \\
Youth Degradation & 6 & 10.0 & 80.0 \\
Health Problem & 6 & 10.0 & 90.0 \\
Child Degradation & 6 & 10.0 & 100.0 \\
Total & 60 & 100.0 & \\
\hline
\end{tabular}

From the table above, it is apparent that Arsenic Contamination is the $2^{\text {nd }}$ most severe problem in Bangladesh. It is voted by almost $20 \%$ respondents. Rest of the people voted lack of security, illiteracy, unemployment, water 
crisis, food adulteration, youth degradation, health problem, child degradation as the $2^{\text {nd }}$ most severe problem each with $10 \%$ responses.

Top $3^{\text {rd }}$ Problem:

Table 3. Top $3^{\text {rd }}$ problem

\begin{tabular}{llccc}
\hline & & Frequency & Percent & Cumulative \% \\
\hline Valid & Illiteracy & 12 & 20.0 & 20.0 \\
& Unemployment & 12 & 20.0 & 40.0 \\
& Child Labor & 6 & 10.0 & 50.0 \\
& Food Adulteration & 6 & 10.0 & 60.0 \\
Drug Addiction & 6 & 10.0 & 70.0 \\
& Health Problem & 6 & 10.0 & 80.0 \\
Child Degradation & 6 & 10.0 & 90.0 \\
& Gender Discrimination & 6 & 10.0 & 100.0 \\
& Total & 60 & 100.0 & \\
\hline
\end{tabular}

Illiteracy and Unemployment both are regarded as the $3^{\text {rd }}$ most severe problem in Bangladesh by $20 \%$ of the respondents each. Other than this, $10 \%$ of people responded voted equally for child labor, food adulteration, drug addiction, health problem, child degradation, and gender discrimination.

Top $4^{\text {th }}$ Problem:

Table 4. Top $4^{\text {th }}$ problem

\begin{tabular}{llccc}
\hline & & Frequency & Percent & Cumulative \% \\
\hline Valid & Illiteracy & 6 & 10.0 & 10.0 \\
& Child Labor & 6 & 10.0 & 20.0 \\
Arsenic Contamination & 6 & 10.0 & 30.0 \\
& Food Adulteration & 6 & 10.0 & 40.0 \\
Women Degradation & 6 & 10.0 & 50.0 \\
Drug Addiction & 6 & 10.0 & 60.0 \\
Health Problem & 6 & 10.0 & 70.0 \\
Child Degradation & 6 & 10.0 & 80.0 \\
& Religious Degradation & 6 & 10.0 & 90.0 \\
& Gender Discrimination & 6 & 10.0 & 100.0 \\
& Total & 60 & 100.0 & \\
\hline
\end{tabular}

The table above shows a stunning picture of the social problems of Bangladesh. Each of the problems has been considered to be the $4^{\text {th }}$ most severe problem of Bangladesh with $10 \%$ responses for each of the problems. In this list remain illiteracy, child labor, arsenic contamination, food adulteration, women degradation, drug addiction, health problem, child degradation, religious degradation, and gender discrimination.

Top $5^{\text {th }}$ Problem:

Table 5. Top $5^{\text {th }}$ problem

\begin{tabular}{llccc}
\hline & & Frequency & Percent & Cumulative \% \\
\hline Valid & Lack of Security & 6 & 10.0 & 10.0 \\
& Unemployment & 6 & 10.0 & 20.0 \\
Child Labor & 6 & 10.0 & 30.0 \\
& Water Crisis & 12 & 20.0 & 50.0 \\
& Arsenic Contamination & 6 & 10.0 & 60.0 \\
& Drug Addiction & 12 & 20.0 & 80.0 \\
& Child Degradation & 6 & 10.0 & 90.0 \\
& Religious Degradation & 6 & 10.0 & 100.0 \\
& Total & 60 & 100.0 & \\
\hline
\end{tabular}


The table above gives a picture of the $5^{\text {th }}$ most severe social problem of Bangladesh. In this stage, $20 \%$ of people considered water crisis and drug addiction each as the problem that deteriorates the socio-economic growth of Bangladesh.

\subsection{Impact of Social Business in Bangladesh}

\subsubsection{Social Business Awareness}

Table 6. Social business awareness

\begin{tabular}{llccc}
\hline & & Frequency & Percent & Cumulative \% \\
\hline \multirow{2}{*}{ Valid } & Yes & 18 & 30.0 & 30.0 \\
\cline { 2 - 5 } & No & 42 & 70.0 & 100.0 \\
& Total & 60 & 100.0 & \\
\hline
\end{tabular}

The above given table shows the awareness of the respondents of the emerging concept social business. Here to say, many respondents have confused social business with social marketing and social networking related business. These respondents are considered as unaware of this concept. Only 30\% of the respondents are found who have knowledge about social business.

\subsubsection{Social Business Impact}

\section{Peoples' Opinions about Social Problem Resolution}

Soon after the respondents were asked about the social business awareness, they were asked about the extent and resolution of social problem prevailing in Bangladesh. The responses are given below in a descriptive statistics table:

Table 7. Impact of social problems

\begin{tabular}{lccccc}
\hline & Descriptive Statistics & & & \\
\hline & $\mathrm{N}$ & Min & Max & Mean & Std. Deviation \\
BD_full_of_social_problems & 60 & 2 & 9 & 4.70 & 2.118 \\
For_Development_eliminate_problems & 60 & 4 & 9 & 6.30 & 1.807 \\
Govt_is_alone_capable & 60 & 1 & 8 & 4.40 & 2.077 \\
Private_firms_should_cooperate & 60 & 4 & 9 & 6.90 & 1.937 \\
Govt. should force firms & 60 & 2 & 8 & 5.60 & 2.027 \\
Private_firms_motivate_more_than_govt & 60 & 1 & 9 & 5.90 & 2.184 \\
\hline
\end{tabular}

The table above shows that average people do not agree (4.70 out of 9) with the notion that "Bangladesh is full of social problems". The responses of this answer varied greatly among the respondents. This picture is clear while looking at the standard deviation.

Almost every one (6.30 out of 9) of the respondents argued that for overall socio-economic development, it is mandatory to eliminate the problems. Even the responses hardly touched the disagree scales in the questionnaire.

In response to the statement "Government is along capable to overcome these problems", versatile responses have been found. On average, people tend to disagree (4.40 out of 9) with the notion. High value of standard deviation dictates the scenario.

Almost every one (6.90 out of 9) urged that private firms should cooperate in order to eradicate the social problems from Bangladesh. Even the responses hardly touched the disagreement scales and the standard deviation seems representative to the fact.

No respondent gave extreme response of agreement and/or disagreement when asked about the force toward the private organizations by the govt. On average, people seem to be agreeing (5.60 out of 9) on the fact, but standard deviation shows significant difference among the responses.

The alarming fact is seen at the last statement that shows the failure of governmental activity. People assert that they get motivated more by private firms than that of govt. The higher standard deviation proves the variation in the speeches, though the overall average is $\mathbf{5 . 9 0}$ out of 9 .

\section{Significance of Social Business in Solving Problems}

As the respondents were asked about the resolution of social problems prevailing in Bangladesh, they were later 
asked about the significance of social business in solving these problems. Hearing the concept of social business, the respondents gave prompt and exclusive responses as depicted in the following table:

Table 8. Regression for significance of social business

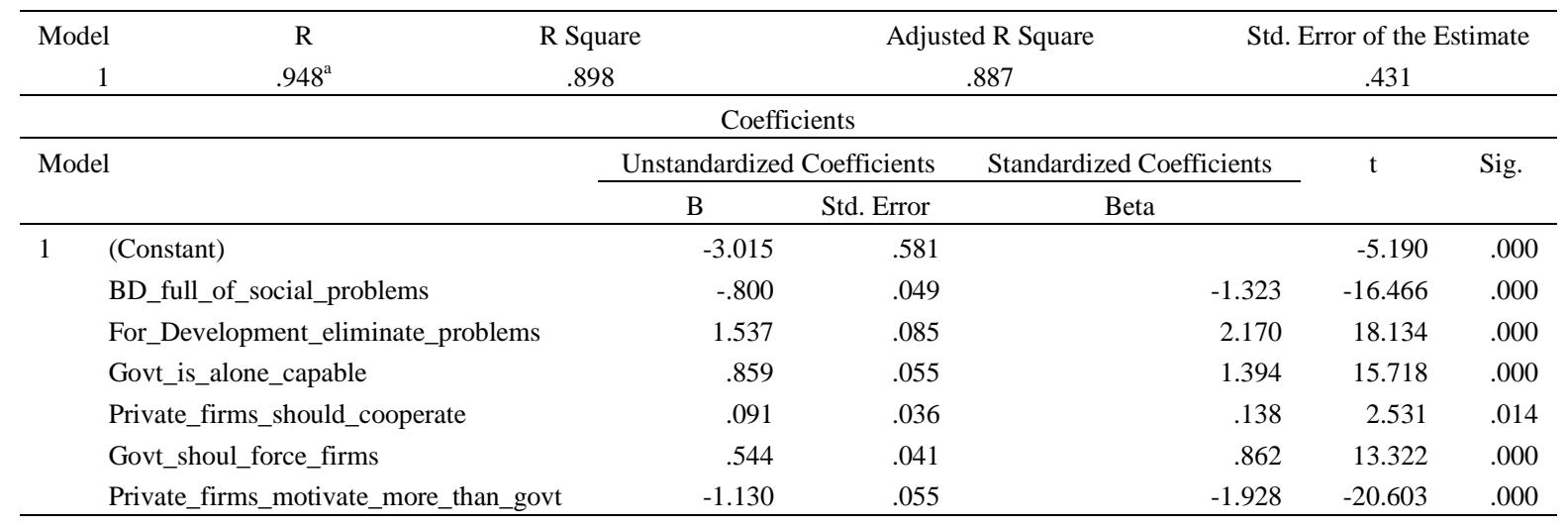

The adjusted R-square shows that almost $90 \%$ of the variation in the dependent variable is accounted for by the variation in the independent variables. It shows that significant number of social problems can be solved by conducting social business. Each and every independent variable is highly significant at a 0.05 level of significance. It shows the importance each independent variable holds in solving the social problems.

\subsection{Social Business Overcoming Social Problems}

Here in this study, a total of 10 problems were selected to be resolved by implementing social business. The respondents were given a problem along with related probable solutions that can be offered by social business.

\subsubsection{Unemployment}

Table 9. Regression for unemployment

\begin{tabular}{|c|c|c|c|c|c|c|c|}
\hline Model & $\mathrm{R}$ & R Square & \multicolumn{2}{|c|}{ Adjusted R Squar } & \multicolumn{3}{|c|}{ Std. Error of the Estimate } \\
\hline 1 & $.809^{\mathrm{a}}$ & .607 & \multicolumn{2}{|r|}{.604} & \multicolumn{3}{|c|}{1.257} \\
\hline \multicolumn{8}{|c|}{ Coefficients } \\
\hline \multirow[t]{2}{*}{ Model } & & & \multicolumn{2}{|c|}{ Unstandardized Coefficients } & Standardized Coefficients & \multirow[t]{2}{*}{$\mathrm{t}$} & \multirow[t]{2}{*}{ Sig. } \\
\hline & & & B & Std. Error & Beta & & \\
\hline \multirow[t]{3}{*}{1} & (Constant) & & 4.450 & .620 & & 7.180 & .000 \\
\hline & Train_unem! & ign_tasks & -.156 & .082 & -.258 & -1.891 & .004 \\
\hline & Give_idea_a & & -.003 & .096 & -.004 & -.030 & .076 \\
\hline
\end{tabular}

The table above shows that for youth development, social business can play really a vital role. The adjusted $\mathrm{R}$-square of 0.604 signifies that $60 \%$ variation in the dependent variable can be accounted for by the variation in the independent variables. Looking at the significance score, the variable indicating "Training unemployed and assigning them task" is significant at a 0.05 level of significance. Whereas, the variable indicating "Giving them idea and capital" is not proved to be significant by a very minimal degree.

\subsubsection{Literacy}

Table 10. Regression for literacy

\begin{tabular}{|c|c|c|c|c|c|c|c|c|}
\hline \multirow{2}{*}{$\begin{array}{r}\text { Model } \\
1 \\
\end{array}$} & \multirow{2}{*}{$\begin{array}{c}\mathrm{R} \\
.711^{\mathrm{a}} \\
\end{array}$} & \multicolumn{2}{|l|}{ R Square } & \multicolumn{2}{|c|}{ Adjusted R Square } & \multicolumn{3}{|c|}{ Std. Error of the Estimate } \\
\hline & & .495 & & \multicolumn{2}{|l|}{.490} & \multicolumn{3}{|c|}{1.284} \\
\hline \multicolumn{9}{|c|}{ Coefficients } \\
\hline \multirow[t]{2}{*}{ Model } & & & Unstandardize & Coefficients & Sta & efficients & $\mathrm{t}$ & Sig. \\
\hline & & & $\mathrm{B}$ & Std. Error & & & & \\
\hline \multirow[t]{4}{*}{1} & (Constant) & & 3.172 & .829 & & & 3.828 & .000 \\
\hline & Free_school_for_s & & -.033 & .084 & & -.053 & -.388 & .07 \\
\hline & Offer_incentive_f & hool & .133 & .090 & & .202 & 1.475 & .046 \\
\hline & Free_school_for_a & & -.044 & .083 & & -.070 & -.536 & .004 \\
\hline
\end{tabular}


From the regression table shown above it is apparent that literacy has a good prospect with the proper implementation of social business at a large scale. The adjusted value of R-square gives $49 \%$ of variation in the dependent variable that is accounted for by the variation in the independent variables. To spread literacy, the Free School for Street Children and Free School for Adult Education are highly significant at 0.05-level. Offering Incentive for Attending School is also significant but at a minimal extent.

\subsubsection{Women Empowerment}

Table 11. Regression for women empowerment

\begin{tabular}{|c|c|c|c|c|c|c|c|}
\hline Model & $\mathrm{R}$ & R Square & \multirow{2}{*}{\multicolumn{2}{|c|}{$\begin{array}{c}\text { Adjusted R-Square } \\
.521 \\
\end{array}$}} & \multicolumn{3}{|c|}{ Std. Error of the Estimate } \\
\hline 1 & $.744^{\mathrm{a}}$ & .554 & & & \multicolumn{3}{|l|}{.885} \\
\hline \multicolumn{8}{|c|}{ Coefficients } \\
\hline \multirow[t]{2}{*}{ Model } & & & Unstandard & Coefficients & Standardized Coefficients & $\mathrm{t}$ & Sig. \\
\hline & & & $\mathrm{B}$ & Std. Error & Beta & & \\
\hline \multirow[t]{5}{*}{1} & (Constant) & & 3.029 & .633 & & 4.784 & .000 \\
\hline & Engage_w & social_development & -.616 & .080 & -1.051 & -7.693 & .000 \\
\hline & Provide_d & animal_to_women & -.495 & .076 & -.819 & -6.482 & .000 \\
\hline & Technical & ssign_tasks & .737 & .122 & 1.040 & 6.058 & .000 \\
\hline & Idea_and & _small_business & .452 & .085 & .733 & 5.332 & .000 \\
\hline
\end{tabular}

While empowering women in the society, the responses are miscellaneous. Though value of coefficient of determination, $\mathrm{R}$, is high, the adjusted R-square has been reduced drastically showing only $52 \%$ variation in independent variable can effect the variation in the dependent variable. And to do this, each of the variables seemed to be significant by the respondents.

\subsubsection{Security}

Table 12. Regression for security

\begin{tabular}{|c|c|c|c|c|c|c|c|c|}
\hline Model & $\mathrm{R}$ & R Square & \multicolumn{3}{|c|}{ Adjusted R Square } & \multicolumn{3}{|c|}{ Std. Error of the Estimate } \\
\hline 1 & $.479^{\mathrm{a}}$ & .229 & \multicolumn{3}{|c|}{.188} & \multicolumn{2}{|c|}{1.153} & \\
\hline \multicolumn{9}{|c|}{ Coefficients } \\
\hline \multirow[t]{2}{*}{ Model } & & & Unstandardized & efficients & Sta & efficients & $\mathrm{T}$ & Sig. \\
\hline & & & $\mathrm{B}$ & Std. Error & & & & \\
\hline \multirow[t]{4}{*}{1} & (Constant) & & 3.994 & .763 & & & 5.234 & .000 \\
\hline & Employ_24h & & .164 & .079 & & .249 & 2.090 & .041 \\
\hline & Reward_poli & & .022 & .076 & & .034 & .285 & .777 \\
\hline & Engage_yout & ecurity & -.263 & .071 & & -.448 & -3.688 & .001 \\
\hline
\end{tabular}

The regression table above shows some confusing phenomenon. The adjusted R-square value is only 0.188 representing only $18.8 \%$ variation in the dependent variable to be accounted for by the variation in the independent variables. At the same time, Engaging youth groups for ensuring security variable is the most significant at 0.05 -level of significance. People have almost no trust in police, as depicted from the table. Employing $24 \mathrm{hr}$ security guard is also significant but at a minimal extent.

\subsubsection{Child Labor}

Table 13. Regression for child labor

\begin{tabular}{|c|c|c|c|c|c|c|c|}
\hline Model & $\mathrm{R}$ & R Square & \multicolumn{2}{|c|}{ Adjusted R Square } & \multicolumn{3}{|c|}{ Std. Error of the Estimate } \\
\hline 1 & $.592^{\mathrm{a}}$ & .367 & \multicolumn{2}{|c|}{.348} & \multicolumn{3}{|c|}{1.257} \\
\hline \multicolumn{8}{|c|}{ Coefficients } \\
\hline \multirow[t]{2}{*}{ Model } & & & Unstandardize & Doefficients & Standardized Coefficients & $\mathrm{t}$ & Sig. \\
\hline & & & $\mathrm{B}$ & Std. Error & Beta & & \\
\hline \multirow[t]{3}{*}{1} & (Constant) & & 4.450 & .620 & & 7.180 & .000 \\
\hline & Admit_chi & _provide_money & -.156 & .082 & -.258 & -1.891 & .064 \\
\hline & Money fo & school & -.003 & .096 & -.004 & -.030 & .976 \\
\hline
\end{tabular}


The table above shows an unclear picture of reality. People of Bangladesh speak against child labor but when the question comes to empower those children with education, the responses changed a lot. The adjusted R-square shows a minimum variation (only 34.8\%) in the dependent variable that can be accounted for by the variation in the independent variables. Here, both the variables seemed to be insignificant. Child labor can hardly be eradicated by admitting children to schools and providing money for attending school that they could have earned working during the school hours.

\subsubsection{Water Crisis}

Table 14. Regression for water crisis

\begin{tabular}{|c|c|c|c|c|c|c|c|}
\hline Model & $\begin{array}{c}\mathrm{R} \\
.849^{\mathrm{a}} \\
\end{array}$ & $\begin{array}{c}\text { R Square } \\
.738 \\
\end{array}$ & \multicolumn{2}{|c|}{$\begin{array}{c}\text { Adjusted R Square } \\
.724 \\
\end{array}$} & \multicolumn{3}{|c|}{$\begin{array}{c}\text { Std. Error of the Estimate } \\
1.163 \\
\end{array}$} \\
\hline \multicolumn{8}{|c|}{ Coefficients } \\
\hline \multirow[t]{2}{*}{ Model } & & Unstandardiz & oefficients & Standardiz & cients & $\mathrm{t}$ & Sig. \\
\hline & & $\mathrm{B}$ & Std. Error & & & & \\
\hline \multirow[t]{5}{*}{1} & (Constant) & 4.020 & .786 & & & 5.114 & .000 \\
\hline & Filter_river_water & -.013 & .076 & & -.020 & -.165 & .070 \\
\hline & Manage_reservoir & .168 & .082 & & .254 & 2.037 & .046 \\
\hline & Dig_deep_tubewell & .021 & .077 & & .034 & .278 & .782 \\
\hline & Provide_arsenic_free_water & -.262 & .072 & & -.447 & -3.635 & .001 \\
\hline
\end{tabular}

The above table shows that $72.4 \%$ variation in the dependent variable can be accounted for by the variation in the independent variables. Apart from these, some of the variables seemed to be insignificant at $5 \%$ significance level. As the solution to the problem, people suggested to manage a reservoir of clean water at the same time they voted for providing arsenic free water.

\subsubsection{Youth Development}

Table 15. Regression for youth development

\begin{tabular}{|c|c|c|c|c|c|c|c|}
\hline Model & $\mathrm{R}$ & R Square & \multicolumn{2}{|c|}{ Adjusted R Square } & \multicolumn{3}{|c|}{ Std. Error of the Estimate } \\
\hline 1 & $.798^{\mathrm{a}}$ & .628 & \multicolumn{2}{|c|}{.610} & \multicolumn{3}{|c|}{1.273} \\
\hline \multicolumn{8}{|c|}{ Coefficients } \\
\hline \multirow[t]{2}{*}{ Model } & & & Unstandardiz & Coefficients & Standardized Coefficients & $\mathrm{t}$ & Sig. \\
\hline & & & $\mathrm{B}$ & Std. Error & Beta & & \\
\hline \multirow[t]{5}{*}{1} & (Constant) & & 3.710 & 1.141 & & 3.252 & .002 \\
\hline & Establish_busir & outh & -.155 & .108 & -.256 & -1.425 & .045 \\
\hline & Youth_for_soc & & .031 & .117 & .043 & .262 & .094 \\
\hline & Motivate_yout & and_idea & .039 & .108 & .064 & .363 & .018 \\
\hline & Technical_train & ath_tasks & .051 & .106 & .077 & .479 & .034 \\
\hline
\end{tabular}

The table gives a picture to develop the youth generation of Bangladesh. Adjusted R-square 0.610 indicates that $61 \%$ variation in the dependent variable is accounted for by the variation in the independent variables. The variable showing involving youth for social development is proved to be insignificant. Rest of the variables, establishing business and employing youth, motivating youth to start business, and training youth and assigning tasks seemed to be significant for overall youth development.

\subsubsection{Health Issues}

Table 16. Regression for health issues

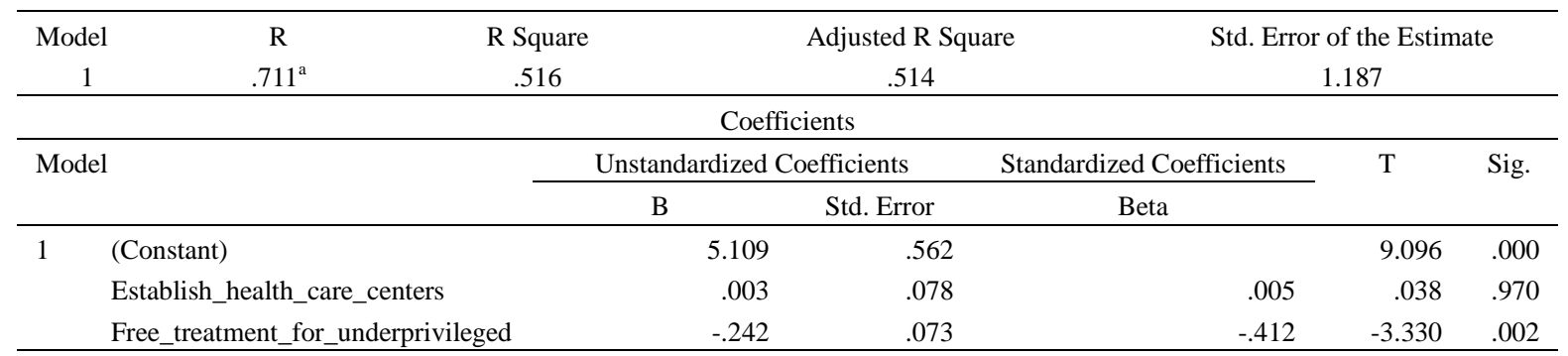


The adjusted R-Square in the above given table shows that $51 \%$ of the variation in the dependent variable can be accounted for the variation in the independent variable. For health issues, establishing low cost health care center is not significant at all. Free treatment for the underprivileged seemed to be the best practice for health improvement of the poor people.

\subsubsection{Slum Dwellers}

Table 17. Regression for slum dwellers

\begin{tabular}{|c|c|c|c|c|c|c|c|}
\hline Model & $\mathrm{R}$ & R Square & \multicolumn{2}{|c|}{ Adjusted R Square } & \multicolumn{3}{|c|}{ Std. Error of the Estimate } \\
\hline 1 & $.811^{\mathrm{a}}$ & .645 & \multicolumn{2}{|r|}{.607} & \multicolumn{3}{|c|}{1.284} \\
\hline \multicolumn{8}{|c|}{ Coefficients } \\
\hline \multirow[t]{2}{*}{ Model } & & & Unstandardiz & Coefficients & Standardized Coefficients & $\mathrm{t}$ & Sig. \\
\hline & & & $\mathrm{B}$ & Std. Error & Beta & & \\
\hline \multirow[t]{4}{*}{1} & (Constant) & & 3.172 & .829 & & 3.828 & .000 \\
\hline & Arrange_sanit & slums & -.033 & .084 & -.053 & -.388 & .070 \\
\hline & Provide_electr & & -.044 & .083 & -.070 & -.536 & .594 \\
\hline & Arrange_habit & & .133 & .090 & .202 & 1.475 & .046 \\
\hline
\end{tabular}

To improve the living of the slum dwellers, the respondents asserted the arrangement of proper habitation. For the table given, the adjusted R-Square dictates more than $60 \%$ variation in the dependent variable can be described by the variation in the independent variable.

\section{Proposing Sustainable Social Business Model}

Taking into consideration each model prescribed by different authors about the proper implementation of social business, here in this part of the paper a sustainable Social Business Model has been developed. The model starts from the problem finding, goes through planning and implementation, and ends with a matrix indicating future actions.

The model starts with the formation of problem set. The problem set consists of all the problems that a country is faced with. This set can be formed taking information from three major sources. Secondary data seemed to be the most informative source. Other than this, personal observation and public application can be collected in order to gather a huge bulk of problems of a society.

A firm can hardly deal with each and every problem of the society. Thus, there should be a list of criteria based on which the firm should screen out each problem and finalize the problem with which the firm is ready to work for. These criteria can be the extent of problem, number of victims, ease of solving, resolution time, and, finally, relatedness to main business. Considering these criteria, the firms finally identify the social problem that the firm tries to solve.

As the problem is identified, the next step is to make a proper planning. An age-old saying goes like "Planning means the half work done". The statement signifies the importance of a good planning. The firm should design a unique framework for the specific selected problem and allocate a particular budget.

The framework developed may need modification for different problems depending on the nature, extent, and resolution of the problems. In some cases, the firm may generate a framework and then allocate a budget to properly run the project. Even in some cases, the firm may fix a particular budget to solve the problem and then design the framework that best suits the budget and solves the problem.

After planning, proper implementation is required to make social business a success against problem elimination from the society. Social business deals with social problems. So, it is highly required to engage people from the society to properly fight the problem. This model asks for the engagement of employees, customers, and the society. As the social business will be carried out along with the main venture, a few employees should be engaged with social business for proper execution of project. Consumers should also be engaged as they are the real sufferers of the problem. The overall society will be engaged as the model deals with social problem.

Soon after proper implementation and execution of the project, the firm should ask itself whether the problem is solved. Taking into account both positive and negative answer to the question, a matrix has been developed following Ansoff's product-market expansion grid.

The matrix shows area coverage horizontally and problems vertically. If the problem that the firm is dealing with is not solved yet, the firm has to stick to the existing problem in the existing coverage. The quadrant is termed as 


\section{Model Renewal.}

If the current problem is solved or brought into organized shape, the firm can have 3 (three) alternative actions:

\subsection{Scope Expansion}

The firm remains into the same geographical area and may try to solve another problem whenever the existing problem is solved. For example, currently the firm is dealing with illiteracy among the hill-tracts inhabitants. If this problem is solved or brought into formal shape, the firm may choose to solve the pure water crisis in that area.

\subsection{Coverage Extension}

The firm may expertise in solving a particular problem and may extend the coverage areas. For example, extracting from the above example, if the firm being expert in removing illiteracy solves the problem, it has to move to other areas where illiteracy is high and solve the problem.

\subsection{Diversification}

Here, the firm focuses on the extent of the problem and the number of the sufferers/victims to that problem. Whenever a problem in a certain area is resolved, the firm tries to jump to another area dealing with another problem based on the urgency of resolution. For example, malnutrition is an extreme problem in the northern part of Bangladesh. Again, illiteracy is a great problem in the southern part. If a firm, solving malnutrition in one area, moves to the other part to solve new problem of illiteracy, this will be called diversification.

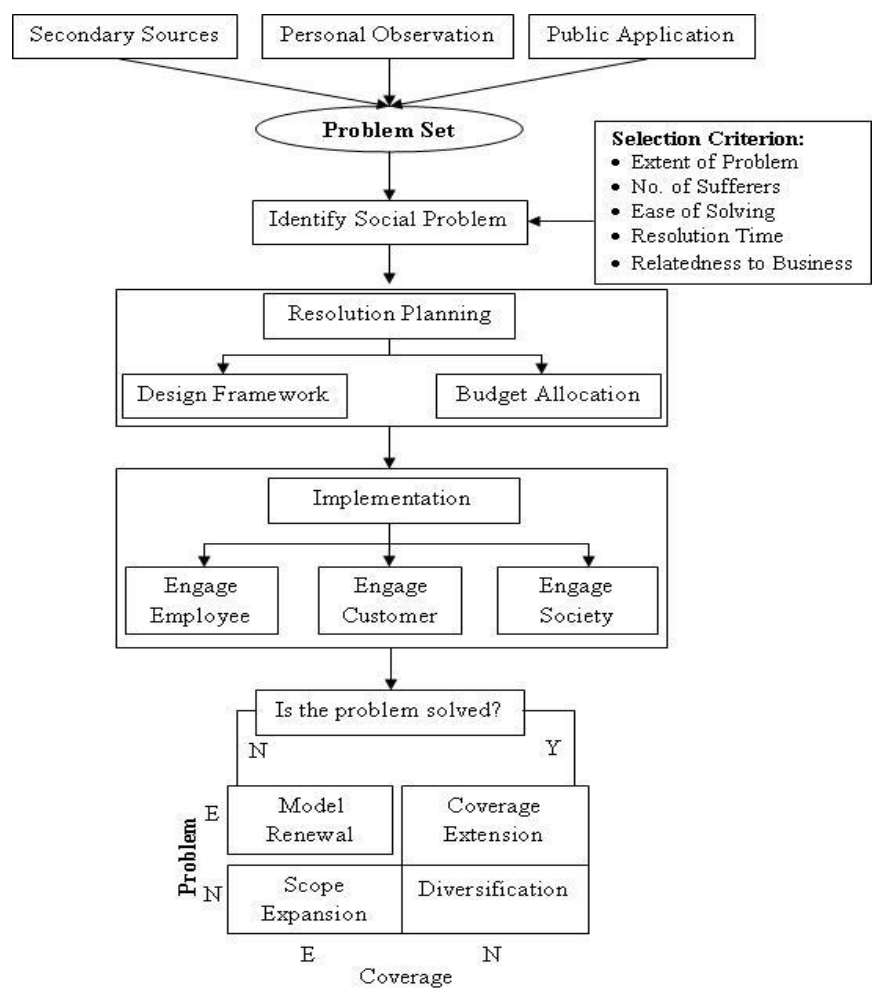

\section{Conclusion}

From the thorough research it is very much apparent that for the socio-economic development of a country or the entire world, Social Business is highly crucial. It serves the under-privileged people, society as a whole, environment, and overall economy of a country. It is evident from the study that participation in social business from all possible organizations can contribute in solving major social problems specifically illiteracy, unemployment, child labor, child development, youth development, security, water crisis, malnutrition, women empowerment, arsenic contamination, and slum dweller of Bangladesh. Besides, a sustainable social business model which has been proposed in the paper requires a holistic approach from planning to implementation as well as to the perseverance of re-implementing the efforts until the targeted one social problem is solved. Hence the future work on this ground will depend on the reasonability and compulsion of including sustainable social business as a mandatory task by every concerned entity of the society and organizations. Though in some parts 
of the world this concept is being practiced in targeting national problems, countries that require practice of this concept mostly lag far behind. It is recommendable that the government should also come forward to establish social business participation as a better alternative to corporate social responsibility performed by private organizations. The proper approach should be targeting one social problem at once and with proper planning solving that specific problem. In case the problem is not solved the firm should stick with one specific problem otherwise it can go for extending scope or coverage of the solution. Finally, it can be said that Social Business should become a mandatory phenomenon, not an optional one in this growing phase of Bangladesh. But the fact is that idea of social business is still in its nascent stage. Being a very new and incomparable subject, it may take some more time to assume a full-fledged and mature structure in both conceptual and operational dimensions. Considering the immense need of poverty alleviation and the perspective in which too much social problem exists, it can be said that winning the war against such problematic society in Bangladesh requires innovative efforts like promoting the idea of social business model and proper implementation of them.

\section{References}

Abt Associates Inc. NGO Financial Sustainability. U.S. Agency for International Development.

Arnaldo, C., David, S., \& Thomas, B. (2010). Strategies and Tools for Stakeholders Engagement - The Handbook. Impressões e Soluções Lda., edition - Leonardo da Vinci Programme, Poland.

Atkinson, G., Dubourg, W. R., Hamilton, K., Munasinghe, M., Pearce, D. W., \& Young, C. E. F. (1997). Measuring Sustainable Development: Macroeconomics and Environment. Edward Elgar, Cheltenham.

Bebbington, J., \& Gray, R. (1997). Sustainable Development and Accounting: Incentives and Disincentives for the Adoption of Sustainability by Transnational Corporations. In C. Hibbit, \& H. Blokdjik (Eds.), Environmental Accounting and Sustainable Development: The Final Report. Limperg Instituut, Amsterdam.

Bylund, P. L., \& Mondelli, M. (2009). Book Review: Creating a World without Poverty: Social Business and Future Capitalism. The Electronic Journal of Sustainable Development, 1(3), 5-7.

Donaldson, C., Baker, R., Cheater, F., Gillespie, M., McHugh, N., \& Sinclair, S. (2011). Social business, health and well-being. Social Business, 1(1), 17-35. https://doi.org/10.1362/204440811X570545

Grameen Health Care Service Ltd. (n. d.). Grameen health care services Ltd.: A social business initiative. Retrieved from http://grameenhealthcareservices.org

Hawken, P. (1993). The Ecology of Commerce. Harper Collins, New York.

Hockerts, N. K. (1993). Sustainability Innovations Ecological land Social entrepreneurship and the Management of Antagonistic Assets. CBS Center for Corporate Social Responsibility.

Hockerts, N. K. (2003). Sustainability Innovations Ecological land Social entrepreneurship and The Management of Antagonistic Assets. CBS Center for Corporate Social Responsibility.

Hossain, Md N. (n. d.). Social business: The new economic concept. Economic Observer.

Mark, S. (2012). Social Business Model - The Sunflowe. Retrieved from http://www.socialmediaexplorer.com/social-media-marketing/social-business-model-the-sunflower/

Ogilvy. (2012). Social Business Solution from Social Business Team. Retrieved from http://johnbell.typepad.com/weblog/2011/12/social-business-solutions-from-social-business-teams.html

Patricia, L. (2003). Four Pillars of Financial Sustainability. Justice Graphics, International Publications Program, 2, 15-21.

Pearce, D. W., Markandya, A., \&Barbier, E. (1989). Blueprint for a Green Economy. Earthscan, London.

Pezzey, J. (1989). Economic Analysis of Sustainable Growth and Sustainable Development. Environment Department Working Paper No. 15, World Bank, Washington D.C.

Sattar, Z. (2012). Social business: Turning Capitalism on its Head. Retrieved from http://www.thedailystar.net/forum/2012/January/social.htm

Scott, P. (2006). World leaders and bottom feeders: Divergent strategies toward social responsibility and resource extraction. In M. Christopher (Ed.), Global corporate power (Boulder, CO: Lynne Rienner).

Sharon, G. F., \& David, R. (n. d.). The Business Imperative for Sustainability: The seven critical success Factors. Betterbricks - The Northwest Energy Efficiency Alliance.

Webinar. (2010). Framework and Matrix: Five Ways Companies Organize for Social Business. 
Wikinomics. (n. d.). 12 Critical Success Factors for Business Platforms. Retrieved from http://www.wikinomics.com/blog/index.php/2009/11/06/12-critical-success-factors-for-business-platforms/

Wimmer, N. (2012). Green energy for a billion poor: How Grameen Shakti created a winning model for social business. MCRE-Verlag.

World Bank. (2004). Responsible Growth for the New Millennium. Integrating Society, Ecology and Economy, Washington D.C.

World Bank. (2007). Building Knowledge Economies Advanced Strategies for Development. World Bank Institute.

Yunus, M. (2007). Creating a world without poverty: Social business and the future of capitalism. The Electronic Journal of Sustainable Development, 1(3).

Yunus, M. (2010). Building Social Business: The New Kid of Capitalism that serves Humanity's most Pressing Needs (1st ed.). Published in US by Public Affairs.

\section{Appendix}

\section{Appendix A}

\section{Question Set for Depth-Interview}

Business means maximizing profit. As a result, the business people think about only profit rather than thinking about poor or other class of people. At that time, NGOs and foreign donors have come forward to help the poor. Ultimately, they help a little and try to build-up their fund and fulfill their personal goals. Government alone cannot help the general people. So, Corporations might initiate to help the society by performing some social works like building hospitals, helping acid-victims, planting trees, giving scholarships, and so on. But doing that type of social activity, firms use these as their promotional activities mainly. In the end, they cannot get any return; at the same time, no social problem is solved. In these circumstances, Nobel peace prize laureate Prof.Muhammad Yunus provided a business concept that will help society, its people, and solve different social business. The concept is termed as "Social Business"

Now share your thinking with us by giving the answer of these questions:

a) Do you think Social Business will help the business people as well as poor people?

b) Do you think these 7 principles are sustainable and feasible to do the business in long run?

c) Do you think the activity undertaken by Social Business is better than that of NGO's?

d) Do you think Social Business is more effective and efficient than CSR activity?

e) Do you think Universities should include Social Business as academic course?

f) What type of governmental problem may arise further in implementing Social Business?

g) How can government help the social business to sustain in the society?

h) If you have enough money, will you be interested to do this business? Which sector will you choose? Why?

\section{Appendix B}

Questionnaire for Field Survey

Part A. Demographics

1. Name :

2. Gender: $\square$ Male $\quad \square$ Female

3. Age:

4. Occupation:

$\begin{array}{ll}\square \text { Student } & \square \text { Service } \quad \square \text { Business } \\ \square \text { Homemaker } & \square \text { Others }\end{array}$

5. Designation (if not student):

6. Education Level:

$\begin{array}{llcc}\square \text { High School } & \square \text { SSC } & \square \text { HSC } & \square \text { Undergraduate } \\ \square \text { Graduate } & \square \text { Postgraduate } & \square \text { Above } & \end{array}$


Part B. Research Questions

1. Do you heard about social business?
$\square$ Yes
$\square$ No

2. What do you think about it?
$\square$ Very good
$\square$ Good
$\square$ No comments
$\square \mathrm{Bad}$
$\square$ Very bad

3. Please rate the following statements from 1 to 9 where 1 indicates Extremely Disagree and 9 indicates Extremely Agree:

\begin{tabular}{|c|c|c|c|c|c|c|c|c|c|}
\hline & $\begin{array}{c}\text { Extremely } \\
\text { Disagree }\end{array}$ & & & & Neutral & & & & $\begin{array}{c}\text { Extremely } \\
\text { Agree }\end{array}$ \\
\hline Bangladesh is full of many social problems & 1 & 2 & 3 & 4 & 5 & 6 & 7 & 8 & 9 \\
\hline For country development, social problems must be eliminated & 1 & 2 & 3 & 4 & 5 & 6 & 7 & 8 & 9 \\
\hline To eliminate those, govt. is alone capable & 1 & 2 & 3 & 4 & 5 & 6 & 7 & 8 & 9 \\
\hline Private firms should come forward to eliminate these & 1 & 2 & 3 & 4 & 5 & 6 & 7 & 8 & 9 \\
\hline People should assist the firms to fight against social problems & 1 & 2 & 3 & 4 & 5 & 6 & 7 & 8 & 9 \\
\hline Govt. should force firms to work against social problems & 1 & 2 & 3 & 4 & 5 & 6 & 7 & 8 & 9 \\
\hline Private firm can motivate people more than govt. do & 1 & 2 & 3 & 4 & 5 & 6 & 7 & 8 & 9 \\
\hline Govt. can motivate people more than private firm do & 1 & 2 & 3 & 4 & 5 & 6 & 7 & 8 & 9 \\
\hline
\end{tabular}

4. According to you, which of the following social problems are the most alarming for country development? Please rank top 5 problems.

\begin{tabular}{|c|c|c|c|}
\hline Problems & Rank & Problems & Rank \\
\hline Lack of Security & & Youth degradation & \\
\hline Illiteracy & & Women Degradation & \\
\hline Unemployment & & Drug Addiction & \\
\hline Child Labor & & Health Problems & \\
\hline Water Crisis & & Child degradation & \\
\hline Arsenic Contamination & & Religion degradation & \\
\hline Food Adulteration & & Gender Discrimination & \\
\hline Others & & Others & \\
\hline
\end{tabular}

5. How can private organizations solve UNEMPLOYMENT in the society?

\begin{tabular}{|c|c|c|c|c|c|c|c|c|c|}
\hline & $\begin{array}{l}\text { Extremely } \\
\text { Disagree }\end{array}$ & & & & Neutral & & & & $\begin{array}{c}\text { Extremely } \\
\text { Agree }\end{array}$ \\
\hline They can train the unemployed and assign them relevant tasks & 1 & 2 & 3 & 4 & 5 & 6 & 7 & 8 & 9 \\
\hline They can give them idea and capital to start own business & 1 & 2 & 3 & 4 & 5 & 6 & 7 & 8 & 9 \\
\hline
\end{tabular}

6. How private organizations help increase LITERACY in the society?

\begin{tabular}{lccccccccc}
\hline & $\begin{array}{c}\text { Extremely } \\
\text { Disagree }\end{array}$ & & Neutral & & \multicolumn{3}{c}{$\begin{array}{c}\text { Extremely } \\
\text { Agree }\end{array}$} \\
\hline They can open free schools for street children & 1 & 2 & 3 & 4 & 5 & 6 & 7 & 8 & 9 \\
They can offer food, clothing, etc. if they attend schools & 1 & 2 & 3 & 4 & 5 & 6 & 7 & 8 & 9 \\
They can open free schools for middle-aged and aged people & 1 & 2 & 3 & 4 & 5 & 6 & 7 & 8 & 9 \\
\hline
\end{tabular}

7. How do firms empower WOMEN in the society?

\begin{tabular}{|c|c|c|c|c|c|c|c|c|c|}
\hline & Extremely & & & & Neutral & & & & Extremely \\
\hline Thoy & 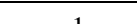 & 0 & 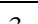 & & 5 & & 7 & & 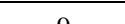 \\
\hline They can engage women to social development projects & 1 & 2 & 3 & 4 & 5 & 6 & 7 & 8 & 9 \\
\hline $\begin{array}{l}\text { They can provide women with domestic animals and manage } \\
\text { their livelihood }\end{array}$ & 1 & 2 & 3 & 4 & 5 & 6 & 7 & 8 & 9 \\
\hline They can train women technically and assign them with tasks & 1 & 2 & 3 & 4 & 5 & 6 & 7 & 8 & 9 \\
\hline They can give them capital and idea to start small business & 1 & 2 & 3 & 4 & 5 & 6 & 7 & 8 & 9 \\
\hline
\end{tabular}

8. How Private Organizations can help improve SECURITY concerns in the society?

\begin{tabular}{lccccccccc} 
& \multicolumn{2}{c}{$\begin{array}{c}\text { Extremely } \\
\text { Disagree }\end{array}$} & & Neutral & & \multicolumn{3}{c}{$\begin{array}{c}\text { Extremely } \\
\text { Agree }\end{array}$} \\
\hline They can assign 24hr well-trained security guard & 1 & 2 & 3 & 4 & 5 & 6 & 7 & 8 & 9 \\
They can reward police for their performance to ensure security & 1 & 2 & 3 & 4 & 5 & 6 & 7 & 8 & 9 \\
They can engage a group of youth to maintain security & 1 & 2 & 3 & 4 & 5 & 6 & 7 & 8 & 9 \\
\hline
\end{tabular}


9. How private organizations can help eliminate CHILD LABOR from society?

\begin{tabular}{|c|c|c|c|c|c|c|c|c|c|}
\hline & $\begin{array}{c}\text { Extremely } \\
\text { Disagree }\end{array}$ & & & & Neutral & & & & $\begin{array}{c}\text { Extremely } \\
\text { Agree }\end{array}$ \\
\hline $\begin{array}{l}\text { They can engage children into free schools and support their } \\
\text { family with equivalent monetary support }\end{array}$ & 1 & 2 & 3 & 4 & 5 & 6 & 7 & 8 & 9 \\
\hline They can pay the children for attending schools & 1 & 2 & 3 & 4 & 5 & 6 & 7 & 8 & 9 \\
\hline
\end{tabular}

10. How private organizations can solve WATER CRISIS in the society?

\begin{tabular}{|c|c|c|c|c|c|c|c|c|c|}
\hline & $\begin{array}{c}\text { Extremely } \\
\text { Disagree }\end{array}$ & & & & Neutral & & & & $\begin{array}{c}\text { Extremely } \\
\text { Agree }\end{array}$ \\
\hline They can filter the river water and supply to the required place & 1 & 2 & 3 & 4 & 5 & 6 & 7 & 8 & 9 \\
\hline They can manage a reservoir and supply water to victims & 1 & 2 & 3 & 4 & 5 & 6 & 7 & 8 & 9 \\
\hline
\end{tabular}

11. How can private firms help eliminate ARSENIC Contamination

\begin{tabular}{|c|c|c|c|c|c|c|c|c|c|}
\hline & $\begin{array}{l}\text { Extremely } \\
\text { Disagree }\end{array}$ & & & & Neutral & & & & $\begin{array}{l}\text { Extremely } \\
\text { Agree }\end{array}$ \\
\hline They can dig deep tube-wells to escape from Arsenic & 1 & 2 & 3 & 4 & 5 & 6 & 7 & 8 & 9 \\
\hline $\begin{array}{l}\text { They can provide arsenic free water in the contaminated area until } \\
\text { resolved }\end{array}$ & 1 & 2 & 3 & 4 & 5 & 6 & 7 & 8 & 9 \\
\hline
\end{tabular}

12. How can firms empower the YOUTH in the society

\begin{tabular}{|c|c|c|c|c|c|c|c|c|c|}
\hline & $\begin{array}{l}\text { Extremely } \\
\text { Disagree }\end{array}$ & & & & Neutral & & & & $\begin{array}{c}\text { Extremely } \\
\text { Agree }\end{array}$ \\
\hline They can establish business and employ youth to work there & 1 & 2 & 3 & 4 & 5 & 6 & 7 & 8 & 9 \\
\hline They can engage youth to social development projects & 1 & 2 & 3 & 4 & 5 & 6 & 7 & 8 & 9 \\
\hline $\begin{array}{l}\text { They can provide youth with idea and capital and motivate } \\
\text { them to start own business }\end{array}$ & 1 & 2 & 3 & 4 & 5 & 6 & 7 & 8 & 9 \\
\hline They can give youth technical training and assign them tasks & 1 & 2 & 3 & 4 & 5 & 6 & 7 & 8 & 9 \\
\hline
\end{tabular}

13. How can firms improve the HEALTH condition of the society?

\begin{tabular}{lccccccccc}
\hline & \multicolumn{1}{c}{$\begin{array}{c}\text { Extremely } \\
\text { Disagree }\end{array}$} & & Neutral & & \multicolumn{3}{c}{$\begin{array}{c}\text { Extremely } \\
\text { Agree }\end{array}$} \\
\hline They can establish health care centers at a least cost & 1 & 2 & 3 & 4 & 5 & 6 & 7 & 8 & 9 \\
They can provide free treatment to underprivileged & 1 & 2 & 3 & 4 & 5 & 6 & 7 & 8 & 9 \\
\hline
\end{tabular}

14. How firms can improve Slum Dwellers living standard?

\begin{tabular}{lccccccccc}
\hline & $\begin{array}{c}\text { Extremely } \\
\text { Disagree }\end{array}$ & & Neutral & & \multicolumn{3}{c}{$\begin{array}{c}\text { Extremely } \\
\text { Agree }\end{array}$} \\
\hline They can arrange sanitation facility for the slum dwellers & 1 & 2 & 3 & 4 & 5 & 6 & 7 & 8 & 9 \\
They can provide them with pure water & 1 & 2 & 3 & 4 & 5 & 6 & 7 & 8 & 9 \\
They can provide them with electricity and gas & 1 & 2 & 3 & 4 & 5 & 6 & 7 & 8 & 9 \\
They can arrange better habitation for them & 1 & 2 & 3 & 4 & 5 & 6 & 7 & 8 & 9 \\
\hline
\end{tabular}

15. Do you have any opinion on how firms can remove the social problems from society?

Thanks for your Cooperation :-

\section{Copyrights}

Copyright for this article is retained by the author(s), with first publication rights granted to the journal.

This is an open-access article distributed under the terms and conditions of the Creative Commons Attribution license (http://creativecommons.org/licenses/by/4.0/). 